\title{
Evaluation of a fluorescent microsphere technique for measuring grazing rates of phagotrophic microorganisms
}

\author{
Michael L. Pace*, Megan D. Bailiff \\ Department of Oceanography, University of Hawaii, 1000 Pope Rd., Honolulu, Hawaii 96822, USA
}

\begin{abstract}
A technique for using fluorescent microspheres (0.6 $\mu \mathrm{m}$ diameter) as a quantitative tracer of feeding by phagotrophic microorganisms was evaluated. Dispersal of the microspheres in seawater was improved by coating the spheres with bovine serum albumin. In laboratory experiments ingestion rates of the ciliate Cyclidium sp. were measured by monitoring the accumulation of spheres within the ciliates over time. Linear rates of ingestion of the spheres were observed for 15 to 30 min prior to the beginning of egestion of the microspheres by the ciliates. The accuracy of the technique was evaluated by: (1) varying the ratio of bacteria to microspheres $(5: 1$ to $15: 1)$ to test whether ciliates discriminated against the spheres, and (2) comparison with continuous culture experiments where ingestion rates were calculated independently. Cyclidium sp. ingested spheres at a rate proportional to their abundance, regardless of the ratio of bacteria to microspheres, suggesting that these protozoans do not discriminate against the microspheres. There was excellent agreement between ingestion rates measured by the microsphere method and calculated from the difference in standing stocks of bacteria in grazed and ungrazed second stages of a two-stage continuous culture. Two species of aplastidic flagellates ingested the microspheres at very low rates in time-course studies. In several field experiments in Kaneohe Bay, daily clearance rates by the nanoplankton were 1 to $2 \%$ of the added concentration of microspheres ( 4 to $6 \times 10^{5}$ spheres $\mathrm{ml}^{-1}$ ). Low rates of grazing by flagellates were possibly related to preservation artifacts and to discrimination against the microspheres. The fluorescent microsphere method appears to be an accurate and sensitive method for measuring feeding rates of some species. The current method, however, does not appear appropriate for measuring in situ grazing rates of all phagotrophs.
\end{abstract}

\section{INTRODUCTION}

Heterotrophic flagellates and ciliates have been proposed as the primary grazers of bacterioplankton and small autotrophic cyanobacteria in marine and fresh waters, because of their relative abundance and ability to feed on small particles (Fenchel 1982a, b, c, Sherr \& Sherr 1984, Porter et al. 1985). Recent attempts have been made to estimate grazing rates, using radiotracers (Hollibaugh et al. 1980, Taylor \& Sullivan 1984), chemical inhibitors (Newell et al. 1983, Fuhrman \& McManus 1984, Sherr et al. 1986, Taylor \& Pace 1987 ), dilution with filtered water to reduce grazing pressure (Landry et al. 1984), size-specific filtration to

\footnotetext{
- Current address: Institute of Ecosystem Studies, The New York Botanical Garden, Mary Flagler Cary Arboretum, Box AB, Millbrook, New York 12545, USA
}

separate protozoan predators from their picoplankton prey (Wright \& Coffin 1984), disappearance of genetically marked minicells (Wikner et al. 1986), and fluorescent microspheres or fluorescently labeled bacteria to measure ingestion directly (Børsheim 1984, Bird \& Kalff 1986, McManus \& Fuhrman 1986, Sherr \& Sherr 1987). Of these methods, the fluorescent microsphere technique offers several advantages.

The method is simple: fluorescent microspheres are added to a sample at a predetermined concentration, a short incubation is required, the grazers are then preserved, and ingestion rates of microspheres are subsequently determined using epifluorescence microscopy. Required incubation times range from a few minutes to a few hours, depending on the concentration of grazers, their prey and grazing rates. This is a distinct advantage over the dilution, filtration, and inhibitor methods, which require incubations of many hours in 
order to observe microbial growth in the absence of predation. The desirability of short incubations has been demonstrated most recently by Ferguson et al. (1984), who document increases in cell size and community succession of bacterioplankton during prolonged bottle incubations. An additional advantage of the fluorescent microsphere method is that grazing rates are measured directly for individual species or functional groups by counting ingested microspheres and determining the ratio of microspheres added to natural food available. The most important grazers on the picoplankton can, therefore, be determined. With the radiotracer, inhibition, dilution, filtration, and minicell methods, one can only infer which grazers are most important.

Application of the fluorescent microsphere technique requires the following assumptions: (1) microspheres remain dispersed during an incubation and do not differentially adsorb to particles or clump, (2) no egestion of ingested microspheres by grazers occurs during an incubation, (3) all grazers will ingest the microspheres, (4) microspheres are not selected against by grazers, (5) addition of the microspheres does not change the food concentration sufficiently to affect feeding rates. The purpose of our study was to test these assumptions for several species in the laboratory and with field assemblages in order to evaluate the accuracy of the method.

\section{METHODS}

Microspheres. Fluorescent microspheres $(2.5 \%$ solids-latex) stained with the dye coumarin (excitation maximum $458 \mathrm{~nm}$, emission maximum $540 \mathrm{~nm}$ ) were used (Polysciences, Inc.). Microspheres with a diameter of $0.57 \mu \mathrm{m}$ were used to mimic the size of natural bacterioplankton. We compared the dispersal characteristics of microspheres added to solutions of $0.2 \mu \mathrm{m}$ filtered distilled water and filtered seawater, because we observed clumping of the spheres in standards made in filtered seawater. We also compared the dispersal characteristics in filtered seawater of microspheres aged in bovine serum albumin $\left(5 \mathrm{mg} \mathrm{ml}^{-1}\right)$ for 24 h or untreated. Counts were performed by adding 0.1 to $0.2 \mathrm{ml}$ of the microsphere solution to $2 \mathrm{ml}$ of filtered water preserved in $2 \%$ formalin, and filtering the spheres onto an irgalan black stained filter. The filters were then air-dried and placed on a slide between 2 drops of oil (Cargille type A), and covered with a Number 1 coverslip. Slides were examined with epifluorescence microscopy using a Zeiss G3 filter set (hereafter referred to as blue light) of the type used for acridine orange direct counts (Hobbie et al. 1977). Counts of 10 to 15 grids per slide were made and the degree of clumping noted by recording microspheres as singles, doublets, triplets, etc.

Laboratory cultures. Laboratory studies were conducted with cuitures of a ciliate, Cyclidium sp. (volume $=405 \mu^{3}$ ) and 2 heterotrophic flagellates, a bodonid $\left(31.7 \mu^{3}\right)$ and a chrysomonad $\left(29.7 \mu^{3}\right)$. Cyclidium sp. and the chrysomonad flagellate were isolated from sediment trap material collected during the VERTEX 4 cruise approximately $1500 \mathrm{~km} \mathrm{NE}$ of Hawaii. The bodonid flagellate was isolated from Kaneohe Bay, Oahu, Hawail. These protozoans were maintained on mixed species bacterial cultures in filtered seawater with a rice grain as a nutrient source. We did not measure the size of the bacteria used in the experiments described below, but most cells were 0.5 to $1 \mu \mathrm{m}$.

Time-course experiments. A series of time-course experiments was performed to determine the cell passage time of microspheres. For the ciliates, microspheres were added to bacterial suspensions at ratios of between 1:5 and 1:15 microspheres per bacterium. Analogous ratios for the flagellate time-course experiments were $1: 1$ to $1: 4$. A higher ratio was used in the experiments with flagellates because of their lower absolute rates of ingestion relative to ciliates. Experiments were initiated by adding the microspheres to a culture and a subsample was taken immediately and preserved in a final solution of either $2 \%$ buffered formalin (ciliates) or $1 \%$ glutaraldehyde (flagellates). This time-zero sample served as a control for adsorption of the microspheres. Additional subsamples were taken periodically during the experiment and preserved.

For ciliates, $5 \mathrm{ml}$ samples from each time point were stained for $5 \mathrm{~min}$ with $0.5 \mathrm{ml}$ of $4^{\prime} 6$-diamidino-2phenylindole (DAPI, stock solution $100 \mu \mathrm{g} \mathrm{ml} \mathrm{m}^{-1}$ ), then filtered onto irgalan black stained Nuclepore filters (usually $2 \mu \mathrm{m}$ pore size), and examined as described above. Epifluorescence due to DAPI which binds DNA was visualized with UV light excitation using the filter set described in Porter \& Feig (1980). Microsphere fluorescence was visualized with blue light excitation. Ciliates had a light green fluorescence under blue light, due apparently to the formaldehyde preservative. Slides were scanned with a Neofluar 100/1.30 oil objective under UV light. When a ciliate was located, the filter set was changed to blue light using a slider, and the number of ingested microspheres counted. At each time point, ca 100 cells were examined.

For flagellates, a similar procedure was followed, except in some experiments cells were stained with proflavine (Haas 1982). With blue light, heterotrophic flagellates fluoresce green after staining with proflavine and flagella are readily visible. Flagellates were either filtered onto $0.8,1$, or 2 um Nuclepore filters, depending on size. Filters were rinsed with $0.2 \mu \mathrm{m}$ filtered seawater as the last few milliliters of sample 
were drawn through. This rinsing helped reduce the background of uningested microspheres in the flagellate experiments where it was necessary to use a high ratio of microspheres to bacteria.

We found it advantageous to search the slides under UV light in order to locate cells. This procedure reduced eye-strain which occurs when searching the slides with blue light, because of the extremely bright fluorescence of the microspheres. In addition, this searching mode reduced a potential source of bias, because phagotrophs which had ingested several microspheres were easier to see when scanning with blue light.

Ratio experiments. To test the hypothesis that microspheres are ingested at the same rate as bacteria, ingestion rates were compared at 3 different bacteria:microsphere ratios. If one assumes a constant selectivity and that the microspheres act as a tracer of bacterial ingestion, then any tendency to discriminate against the microspheres by the grazers should be evident at lower bacteria: microsphere ratios. Experimental protocol and counting techniques were similar to those described above for the time-course experiments.

Continuous culture experiments. To further test the accuracy of the microsphere method, a series of experiments was run using a 2-stage continuous culture. A low organic $f / 2$ medium (Guillard \& Ryther 1962) using casamino acid $\left(2 \mathrm{mg} \mathrm{l}^{-1}\right)$ and sucrose $\left(1.1 \mathrm{mg} \mathrm{l}^{-1}\right)$ as carbon sources was pumped into the first stage which was inoculated from a mixed bacteria seawater culture, and subsequently one of the 2 second-stage reactors was inoculated with Cyclidium sp. The second stage, therefore, consisted of a control reactor with bacteria and a grazed reactor with bacteria and ciliates (Fig. 1).

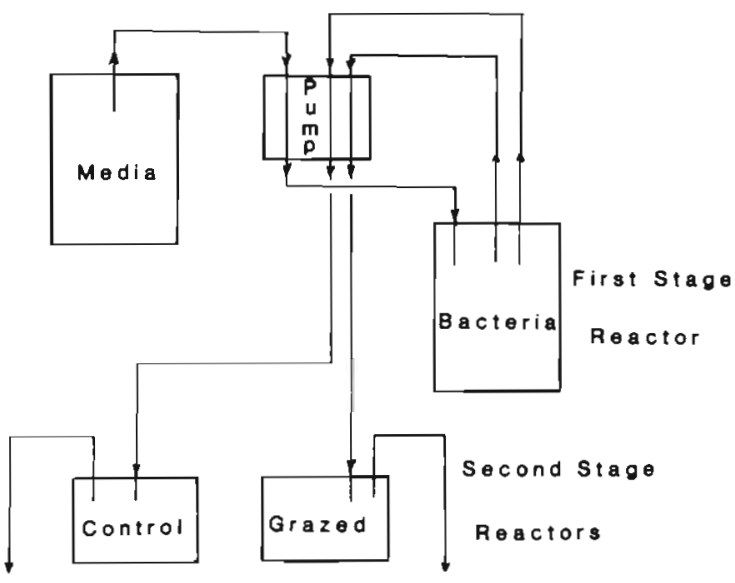

overflow

Fig. 1. Schematic of 2-stage continuous culture experiment. Flows indicated by arrows. Filtered air was pumped into each reactor. Reactors were continuously mixed with stir bars, and sampling was done with syringes through sealed stoppers
The continuous culture experiments were run in a constant temperature incubator $\left(20^{\circ} \mathrm{C}\right)$ in the dark at a dilution rate of $1 \mathrm{~d}^{-1}$. The first-stage and the 2 secondstage reactors were sampled daily and acridine orange direct counts (Hobbie et al. 1977) were made to determine the concentrations of bacteria in each of the 3 reactors and the concentration of protozoans in the single second-stage reactor. The mortality rate $\lambda$ (due to grazing and/or nonpredatory mortality) in the 2 second-stage reactors can be calculated as follows:

$$
\begin{aligned}
& \mathrm{dN} / \mathrm{dt}=\mathrm{D}\left(\mathrm{N}_{0}-\mathrm{N}\right)-\lambda \mathrm{N} \\
& \mathrm{d} \mathrm{N}^{\prime} / \mathrm{dt}=\mathrm{D}\left(\mathrm{N}_{0}-\mathrm{N}^{\prime}\right)-\lambda^{\prime} \mathrm{N}^{\prime}
\end{aligned}
$$

where $N_{0}=$ bacterial concentration in the first stage: $\mathrm{N}=$ bacterial concentration in the ungrazed second stage; $\mathrm{N}^{\prime}=$ bacterial concentration in the second stage with protozoan grazers; $D=$ growth rate as determined by dilution rate, which was the same for all chambers. At steady state, the mortality rate in each second-stage reactor can be calculated as:

$$
\begin{aligned}
& \lambda=\mathrm{D}\left(\mathrm{N}_{0} / \mathrm{N}-1\right) \\
& \lambda^{\prime}=\mathrm{D}\left(\mathrm{N}_{0} / \mathrm{N}^{\prime}-1\right)
\end{aligned}
$$

Knowing the death rates, the grazing rate is calculated as the difference between $\lambda$ and $\lambda^{\prime}$, and the ingestion rate is the grazing rate divided by the steady-state concentration of ciliates in the second stage. The continuous culture was allowed to run for at least 1 wk ( 7 dilution periods) after the inoculation of protozoans in order to establish steady-state conditions. From the standing stock counts, ingestion rates were estimated successively over a 4- to 6-d period. A sample was then drawn from the reactor containing grazers, and the ingestion rates were measured directly, using the microsphere method as described above for the time course experiments. In the experiments with ciliates, samples were taken at 0,15 , and $30 \mathrm{~min}$ after the addition of microspheres. Microspheres per ciliate, bacteria concentrations, and microsphere concentrations were determined independently in each of 3 subsamples from the continuous culture to provide 3 replicate measurements of ingestion at 2 times.

Field experiments. Field trials of the microsphere method were conducted in Kaneohe Bay. In an initial experiment, 2 concentrations of microspheres were added to determine an appropriate concentration for field experiments. In a second experiment, we performed a time-course study. We also compared the DAPI and proflavine staining techniques for observing the cells and counting ingested microspheres in field preparations. In all experiments, water was collected from a depth of $1 \mathrm{~m}$ in the south sector of the Bay (see Smith et al. 1981 for detailed description of study site). Samples were returned to the field laboratory 
(Hawaiian Institute of Marine Biology), and slides were immediately made for epifluorescent microscope counts of picoplankton and nanoplankton. For this purpose, we used the proflavine staining technique (Haas 1982, Landry et al. 1984). Two $5 \mathrm{ml}$ subsamples were filtered under low vacuum pressure $(<200 \mathrm{~mm} \mathrm{Hg})$ onto irgalan black stained $0.2 \mu \mathrm{m}$ Nuclepore filters for picoplankton counts, and two $20 \mathrm{ml}$ subsamples were filtered onto $1.0 \mu \mathrm{m}$ filters for nanoplankton counts. Slides were frozen and subsequently counted at $1000 \times$ magnification by a combination of grid, field, and transect methods, depending on the density of the organisms of interest. In the final experiment comparing the 2 staining techniques, $2 \mathrm{ml}$ subsamples for bacterial counts were enumerated after staining with DAPI, and nanoplankton were counted on the original $5 \mathrm{ml}$ subsamples taken for picoplankton. This procedure was necessary because of the unusually high concentrations of bacteria and detritus in the water column at the time of the experiment (see 'Results').

Experiments were initiated by adding a known concentration of $0.6 \mu \mathrm{m}$ microspheres to a $500 \mathrm{ml}$ subsample of the original water sample. In the initial experiment, microspheres were added at concentrations of approximately 5 and $10 \times 10^{5} \mathrm{ml}^{-1}$. After a $2 \mathrm{~h}$ incubation, samples were preserved with Lugol's solution. Two $10 \mathrm{ml}$ subsamples of the preserved experimental material were subsequently cleared with a few drops of $\mathrm{Na}_{2} \mathrm{~S}_{2} \mathrm{O}_{3}$ (Pomroy 1984), stained with $0.5 \mathrm{ml}$ of DAPI, and filtered onto $1 \mu \mathrm{m}$ filters with extensive filtered seawater rinsing as described above for the flagellate experiments. In the time-course experiment, a known concentration of $0.6 \mu \mathrm{m}$ microspheres $\left(1 \times 10^{8} \mathrm{ml}^{-1}\right)$ was added to $500 \mathrm{ml}$ of bay water to make a final concentration of $5.0 \times 10^{5} \mathrm{ml}^{-1}$. Time-point samples were taken at $0,1,2,4$, and $8 \mathrm{~h}$. At each time point, two $10 \mathrm{ml}$ subsamples were preserved with $1 \mathrm{ml}$ of a $10 \%$ solution of glutaraldehyde in filtered seawater, immediately stained with DAPI, and filtered onto $1 \mu \mathrm{m}$ filters. The 2 staining techniques were compared by taking four $10 \mathrm{ml}$ subsamples at 0 and $3 \mathrm{~h}$ and preparing the 2 slides with proflavine stain and 2 slides with DAPI stain, using the techniques described above. After preparation, slides were frozen and subsequently examined under $1000 \times$ magnification.

In the field experiments, community ingestion rates were determined by counting the number of microspheres ingested by nanoplankton in transects (approximately $10 \mathrm{~mm} \times 0.1 \mathrm{~mm}$ ) across each slide. Exact transect areas were measured using the stage micrometer to determine the length of the transect and an ocular micrometer set perpendicular to the length axis to determine the width of the transect. Four transects were done for each slide and the ingestion rates represent the means of 2 duplicate slides. Ingestion rates of microspheres were calculated by dividing the number of microspheres ingested by the ratio of the transect area (cumulative for 4 transects) to the slide area and by dividing by the volume filtered $(10 \mathrm{ml})$ and the time. This calculation yields a rate in terms of microspheres ingested by $1 \mathrm{ml}$ of the nanoplankton community per unit time. No attempt was made to calculate the ingestion rates of individual species or functional groups (i.e. nanoplankton without chlorophyll). Clearance rates of the nanoplankton community (in $1 \mathrm{ml}$ ) are calculated by dividing the ingestion rate by the concentration of microspheres per ml.

\section{RESUITS}

\section{Microspheres}

Microspheres remained dispersed in distilled water $\left(\mathrm{dH}_{2} \mathrm{O}\right)$, but clumped significantly within $2 \mathrm{~h}$ in filtered seawater (FSW) (Table 1). When microsphere stocks

Table 1. Percentage of microspheres occurring singly with time in: distilled water $\left(\mathrm{dH}_{2} \mathrm{O}\right)$ versus filtered seawater (FSW) and FSW versus FSW with microspheres pre-treated in $5 \mathrm{mg}$ $\mathrm{ml}^{-1}$ bovine serum albumin (BSA)

\begin{tabular}{|cccccc|}
\hline $\begin{array}{c}\text { Incubation } \\
\text { time }\end{array}$ & $\mathrm{dH}_{2} \mathrm{O}$ & vs & FSW & FSW & $\begin{array}{c}\text { FSW } \\
+ \\
\text { BSA }\end{array}$ \\
\hline $2 \mathrm{~h}$ & 86.6 & 23.9 & & \\
$4 \mathrm{~h}$ & 83.5 & 8.2 & 56.8 & 92.0 \\
$24 \mathrm{~h}$ & & & 24.3 & 92.4 \\
\hline
\end{tabular}

were made up in $\mathrm{dH}_{2} \mathrm{O}$ with $5 \mathrm{mg} \mathrm{ml}^{-1}$ of bovine serum albumin (BSA), the microspheres remained dispersed for at least $24 \mathrm{~h}$ after addition to FSW (Table 1). We therefore made up stock solutions of microspheres in $\mathrm{dH}_{2} \mathrm{O}$ with $\mathrm{BSA}$ and, prior to an experiment, added a subsample of the stock solution to FSW and counted to make a microsphere standard (typically $10^{7}$ to $10^{8}$ spheres $\mathrm{ml}^{-1}$ ).

\section{Time-course experiments}

An initial long time-course experiment with Cyclidium sp. was performed at a bacterial concentration of $5.12 \times 10^{6}$ cells $\mathrm{ml}^{-\mathrm{t}}$ and a bacteria:microsphere ratio of 8.5. The rate of uptake of microspheres slowed after 20 min, because microspheres were egested (Fig. 2A). Egested microspheres were visible in the latter time point samples as clumps of spheres apparently coated with either a membrane or an organic matrix. A series of shorter time-course experiments indicated that 


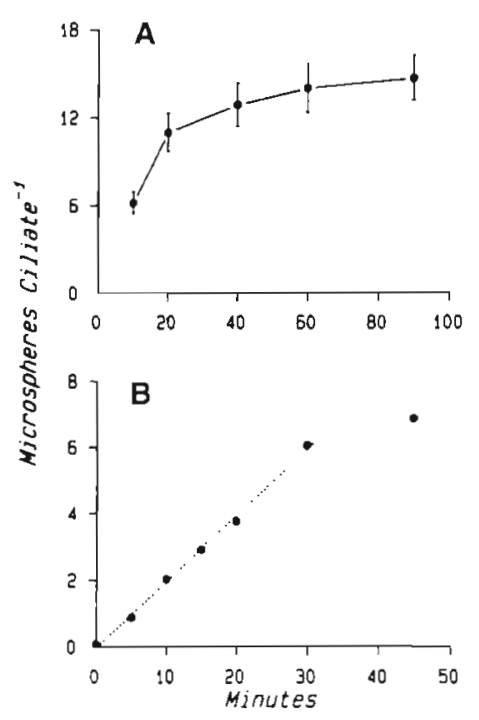

Fig. 2. Time course of ingestion of $0.6 \mu \mathrm{m}$ microspheres by the ciliate, Cyclidium sp. (A) Long time course with $95 \%$ confidence intervals for each time point measurement; (B) short time course with fitted regression line over the linear portion of the experiment ( 0 to $30 \mathrm{~min}$ )

uptake of the microspheres was generally linear for the first 15 to $30 \mathrm{~min}$. In the experiment illustrated in Fig. $2 \mathrm{~b}$, a linear regression model provided an excellent fit to the data over the first 30 min of the time course $\left(\mathrm{r}^{2}\right.$ $=0.997)$. Microspheres were beginning to be egested after $30 \mathrm{~min}$, as indicated by the decrease in the rate of uptake at 45 min (Fig. 2B). The cell passage time of the microspheres appears to be a function of the ingestion rate of the microspheres, which is related to both the absolute ingestion rate and the relative concentration of microspheres to bacteria.

Bacterial ingestion rates are estimated by multiplying the number of microspheres per grazer by the bacterial concentration divided by the microsphere concentration. The most precise estimate of the number of ingested microspheres per grazer is provided by the mean value of the regression fit to the linear timecourse data. For the experiment illustrated in Fig. 2B, the regression mean was 2.62 microspheres ciliate ${ }^{-1}$ in $13.33 \mathrm{~min}$. Bacteria and microsphere concentrations were 3.16 and $0.522 \times 10^{6} \mathrm{ml}^{-1}$ respectively, yielding a calculated ingestion rate of bacteria of 71.4 bacteria ciliate ${ }^{-1} \mathrm{~h}^{-1}$. An estimate of the coefficient of variation for the ingestion rate of bacteria is provided by propagation of error techniques, using the following equation:

$$
\mathrm{CV}_{1}=\left(\mathrm{CV}_{\mathrm{r}}^{2}+\mathrm{CV}_{\mathrm{b}}^{2}+\mathrm{CV}_{\mathrm{m}}^{2}\right)^{0.5}
$$

where $\mathrm{CV}_{\mathrm{x}}=$ coefficient of variation for mean value of the regression ( $\mathrm{r}$ ); $\mathrm{b}=$ bacterial concentration; $\mathrm{m}=$ microsphere concentration; $i=$ derived value for ingestion rate. CVs for the ciliate grazing experiment

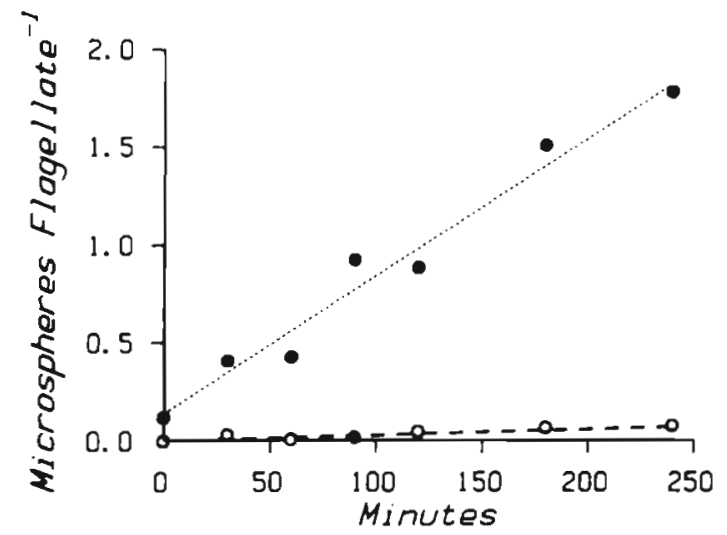

Fig. 3. Time course of ingestion of $0.6 \mu \mathrm{m}$ microspheres by 2 species of heterotrophic flagellates. For the chrysomonad species $(\ldots .$.$) , line represents linear regression fit. For the$ bodonid species $(---)$, line connects points

(Fig. 2B) were 5.14, 28.6, and $22.1 \%$ for the microsphere ingestion rate, bacterial concentration, and microsphere concentration respectively. Using Eq. 3, a CV of $36.5 \%$ is calculated for the bacterial ingestion rate. The precision of the estimate is limited largely by the variability of counting bacteria and microspheres.

In the time-course experiments with flagellates, the bodonid did not ingest microspheres to any significant degree at bacterial concentrations of $3.21 \times 10^{6}$ cells $\mathrm{ml}^{-1}$ and a bacteria: microsphere ratio of $1.2: 1$ (Fig. 3 ). On the other hand, microspheres were ingested by the chrysomonad species, at bacterial concentrations of $3.90 \times 10^{6} \mathrm{ml}^{-1}$ and a bacteria:microsphere ratio of 1.2: 1 (Fig. 3). Ingestion rates were well described by a linear regression model over the $4 \mathrm{~h}$ period of the time course $\left(r^{2}=0.97\right)$. The calculated bacterial ingestion rate was 0.66 bacteria flagellate $\mathrm{h}^{-1}$. This value is considerably lower than estimates from previous studies (see 'Discussion').

\section{Ratio experiments}

In an experiment with the ciliate Cyclidium sp., ingestion rates were linear for $15 \mathrm{~min}$ at bacteria: microsphere ratios of $5: 1$, and 30 min at ratios of $11: 1$ and $15: 1$. Ingestion rates and their standard deviations were equivalent at these 3 ratios (Table 2). These data imply that there is no discrimination against the microspheres by Cyclidium and that the microsphere method provides an accurate measure of ingestion. CVs for the individual estimates without replication ranged from 23 to $30 \%$ (Table 2). If each ratio is treated as a replicate, the coefficient of variation is $7.7 \%$. In addition, the equivalence of ingestion rates at different bacteria-tomicrosphere ratios supports the assumption that the 
Table 2. Means and standard deviations for the rate of microsphere consumption by Cyclidium sp. (regression mean of time versus microspheres ciliate ${ }^{-1}$, bacterial concentration, microsphere concentration, and ingestion rates for 3 bacteria:microsphere ratios

\begin{tabular}{|c|c|c|c|c|c|}
\hline \multirow{2}{*}{\multicolumn{2}{|c|}{$\begin{array}{l}\text { Bacteria Microspheres } \\
\left(10^{5} \text { cells or spheres } \mathrm{ml}^{-1}\right)\end{array}$}} & \multirow[t]{2}{*}{ Ratio } & \multicolumn{2}{|c|}{ Regression means } & \multirow{2}{*}{$\begin{array}{c}\text { Ingestion rate } \\
\text { (bacteria } \\
\text { ciliate }^{-1} \mathrm{~h}^{-1} \text { ) }\end{array}$} \\
\hline & & & Time (min) & $\begin{array}{c}\text { Ingestion } \\
\text { (spheres ciliate }{ }^{-1} \text { ) }\end{array}$ & \\
\hline $8.64 \pm 1.08$ & $1.71 \pm 0.25$ & $5: 1$ & 7.5 & $0.94 \pm 0.21$ & $37.77 \pm 11.15$ \\
\hline $11.31 \pm 0.96$ & $1.05 \pm 0.07$ & $11: 1$ & 10.7 & $0.63 \pm 0.12$ & $37.77 \pm 8.78$ \\
\hline $8.70 \pm 0.80$ & $0.58 \pm 0.06$ & $15: 1$ & 10.7 & $0.39 \pm 0.07$ & $32.90 \pm 7.65$ \\
\hline
\end{tabular}

microspheres, even at the highest concentration added, are not substantially changing the food concentration and thereby affecting the ingestion rate.

In a similar ratio experiment with the chrysomonad flagellate, ingestion rates (bacteria flagellate $\mathrm{h}^{-1}$ ) were $0.14,0.19$, and 0.24 at bacteria-to-microsphere ratios of $0.8: 1,2.4: 1$, and $4.5: 1$, respectively. The trend for calculated ingestion rates to decrease as the relative concentration of microspheres increases (i.e. low bacteria-to-microsphere ratios) suggests that the flagellates discriminate against the microspheres. Ingestion of the microspheres, however, occurred at such a low rate that no firm conclusion regarding discrimination is possible.

\section{Continuous culture experiments}

The equivalence of microsphere ingestion and bacteria ingestion by Cyclidium sp. was further confirmed by the comparison with independent estimates of ingestion in 2 continuous culture experiments (Table 3). Ingestion rates were calculated from daily differences between the 2 stages over a $4 \mathrm{~d}$ period in the first experiment and a $6 \mathrm{~d}$ period in the second experiment. Ingestion rates measured using the microsphere method at 15 and 30 min were similar, so means of these 2 values for each of 3 replicates were used to calculate rates. Mean ingestion rates were not significantly different in either of the 2 experiments (t-test, Expt 1: p >0.5, Expt 2: p. >0.9). The difference in the ingestion rate of Cyclidium between Experiments 1 and 2 appeared to be a function of the 2 -fold difference in bacterial concentrations in the first stage (Table 3 ).

\section{Field experiments}

When microsphere concentrations of $1 \times 10^{6} \mathrm{ml}^{-1}$ were used, the background concentration of spheres remaining on the filter was so high that scanning the slide and detecting nanoplankton which had ingested microspheres was extremely difficult. It was possible to determine ingestion of microspheres at concentrations of $5 \times 10^{5} \mathrm{ml}^{-1}$, although the background concentrations of microspheres reduced the quality of the microscopic image substantially. Time-zero controls were used to correct for adsorption of microspheres which could not be distinguished from actual ingestion. Control corrections were $<5 \%$ of the total in all samples except for the $1 \mathrm{~h}$ sample in the time-course experiment, where the control correction was $13 \%$ of the total.

Ingestion of microspheres by nanoplankton could be determined both in proflavine and DAPI stained preparations. With the proflavine stain, it was frequently difficult to see the grazers if they contained several microspheres, because the intense fluorescence of the microspheres obscured the nanoplankton cells. It was also tedious to scan these slides, because of the bright fluorescence of the microspheres which were captured on the filter. With DAPI, cells were clearly visible under UV light and could be checked for microspheres under blue light. Microspheres were also faintly visible under

Table 3. Continuous culture conditions and comparison of ingestion rates by Cyclidium sp. in 2 experiments. Mean bacterial concentrations are presented for the first stage $\left(\mathrm{N}_{0}\right)$ and ungrazed $(\mathrm{N})$ and grazed $\left(\mathrm{N}^{\prime}\right)$ second-stage reactors. Ciliate ingestion rates were calculated daily from differences in steady-state standing stocks and measured using the microsphere method. Ingestion rates are means \pm 1 standard deviation

\begin{tabular}{|c|c|c|c|c|c|c|c|}
\hline \multirow[t]{2}{*}{ Experiment } & \multirow[t]{2}{*}{ Days } & \multicolumn{3}{|c|}{$\begin{array}{c}\text { Mean bacterial concentration } \\
\left(10^{6} \text { cells } \mathrm{ml}^{-1}\right)\end{array}$} & \multirow{2}{*}{$\begin{array}{c}\text { Cyclidium } \\
\text { concentration } \\
\left(10^{4} \text { cells } \mathrm{ml}^{-1}\right)\end{array}$} & \multicolumn{2}{|c|}{$\begin{array}{c}\text { Ingestion } \\
\text { (bacteria ciliate } \mathrm{h}^{-1} \text { ) }\end{array}$} \\
\hline & & $N_{0}$ & $N$ & $N^{\prime}$ & & Calculated & Measured \\
\hline 1 & 4 & 4.01 & 3.92 & 1.33 & 1.48 & $76.21 \pm 28.9$ & $68.8 \pm 4.43$ \\
\hline 2 & 6 & 2.00 & 1.98 & 0.79 & 1.41 & $33.3 \pm 4.04$ & $32.9 \pm 7.07$ \\
\hline
\end{tabular}


UV light, and the slide could be scanned using UV light. Higher ingestion rates, however, were measured for the filters stained with proflavine $(\overline{\mathrm{x}}=473$ microspheres $\left.\mathrm{ml}^{-1} \mathrm{~h}^{-1}\right)$ versus DAPI $(\overline{\mathrm{x}}=332$ microspheres $\left.\mathrm{ml}^{-1} \mathrm{~h}^{-1}\right)$. Replication was not sufficient to test for a significant difference in the rates measured. Despite this possible difference, DAPI is the stain of choice, because the optical quality of the preparation is

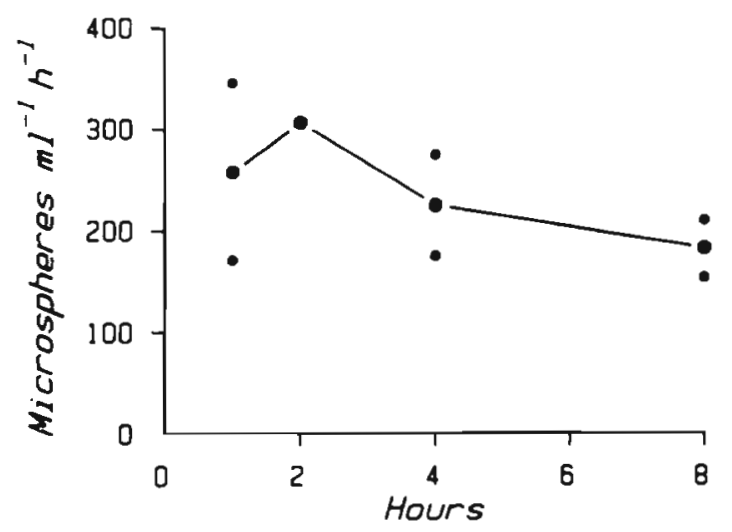

Fig. 4. Time-course of the clearance rate of microspheres by the nanoplankton community of Kaneohe Bay, Hawaii. Mean and range of 2 duplicates presented except for $2 \mathrm{~h}$ time point

superior and because both filter sets of the microscope can be used for counting microspheres and identifying nanoplankton cells.

Observations of the nanoplankton ingesting microspheres revealed that $20 \%$ of the organisms contained chlorophyll, suggesting that mixotrophy may be common in some microflagellate species. Other recent studies (Bird \& Kalff 1986, Estep et al. 1986) have provided field evidence that some autotrophs are also phagotrophic. An additional important observation was that only a small percentage of nanoplankton without chlorophyll ingested microspheres.

In the time-course experiment, microsphere ingestion rates tended to drop slightly over the time-course (Fig. 4), but the range of duplicate measurements overlapped at the beginning and end of the experiment. Short-time courses are preferable to avoid egestion and bottle effects, but the proportion of cells ingesting microspheres increases with time. More cells containing microspheres were counted at the $8 \mathrm{~h}$ time-point, and this appeared to decrease the variance in the estimate as reflected by the narrow range about the mean value at $8 \mathrm{~h}$ (Fig. 4). We attempted to run shorter ( $<1 \mathrm{~h}$ ) timecourse experiments, but very few cells ingested microspheres during the first hour, preventing an accurate estimate of the community ingestion rate. The relatively long incubation times used in the time-course experiment and the other 2 field experiments $(2$ and $3 \mathrm{~h}$ ) probably result in an underestimate of the actual ingestion rate because of egestion of the microspheres during the incubation.

Experiments 1 and 2 represented typical field conditions in Kaneohe Bay in terms of the concentrations of picoplankton and nanoplankton (Landry et al. 1984, authors' unpubl. observations). Bacterial and nanoplankton concentrations were unusually high in Experiment 3 (Table 4), probably due to high inputs of allochthonous materials into the Bay because of flushing in the watershed by heavy rains. For the 3 experiments, ingestion rates by the nanoplankton community in $1 \mathrm{ml}$ were from 200 to 400 microspheres $\mathrm{h}^{-1}$. These represent daily clearance rates of only 1 to $2 \%$ of the microspheres per day (Table 4). If these values are extrapolated to clearance rates on the picoplankton (bacteria, cyanobacteria, and eucaryotes), the impact of nanoplankton grazing appears to be minimal.

Table 4. Summary of 3 field experiments with water samples from Kaneohe Bay, Hawaii. All densities are in numbers mi ${ }^{-1}$. Ingestion and clearance rates are for $1 \mathrm{ml}$ of the nanoplankton community

\begin{tabular}{|c|c|c|c|}
\hline & \multicolumn{3}{|c|}{ Experiment } \\
\hline & 1 & 2 & 3 \\
\hline Date & 5 Jul 1985 & 25 Jul 1985 & 13 Nov 1985 \\
\hline Bacteria & $1.67 \times 10^{6}$ & $2.33 \times 10^{6}$ & $8.35 \times 10^{6}$ \\
\hline Cyanobacteria & $9.50 \times 10^{4}$ & $1.15 \times 10^{5}$ & $1.92 \times 10^{5}$ \\
\hline Eucaryote picoplankton & $4.38 \times 10^{3}$ & $4.71 \times 10^{3}$ & $5.57 \times 10^{3}$ \\
\hline Nanoplankton (with chloroplasts) & $3.84 \times 10^{3}$ & $5.45 \times 10^{3}$ & $1.29 \times 10^{4}$ \\
\hline Nanoplankton (without chloroplasts) & $1.39 \times 10^{3}$ & $3.03 \times 10^{3}$ & $5.89 \times 10^{3}$ \\
\hline Microspheres & $4.02 \times 10^{5}$ & $4.98 \times 10^{5}$ & $6.06 \times 10^{5}$ \\
\hline Microspheres ingested $\mathrm{h}^{-1}$ & 212 & $244^{\circ}$ & $402 \cdots$ \\
\hline Clearance rates $\left(\mathrm{ml} \mathrm{d}^{-1}\right)$ & 0.0127 & 0.0118 & 0.0159 \\
\hline \multicolumn{4}{|l|}{ - Mean of 11 time-point values } \\
\hline - Mean of DAPI and proflavine prepa & & & \\
\hline
\end{tabular}




\section{DISCUSSION}

The principal assumptions of the fluorescent microphere method were met in the experiments with $\mathrm{Cyc}$ lidium sp. Microspheres incubated in BSA remained well dispersed during the experiments. For timecourses less than $30 \mathrm{~min}$, there was no egestion of the microspheres, and ingestion was accurately measured by the accumulation of microspheres in the cells. Further, additions of microspheres at the bacterial concentrations employed did not change the feeding rate, confirming that the microspheres are suitable tracers.

The microsphere method did not appear to be suitable for measuring ingestion rates of the cultured flagellates or for the nanoplankton community of Kaneohe Bay. For the bodonid species investigated, microspheres were not ingested. Rates of bacterial ingestion measured for the chrysomonad species ranged from 0.14 to 0.66 bacteria flagellate ${ }^{-1} \mathrm{~h}^{-1}$ at bacterial concentrations of 5 to $39 \times 10^{5}$ cells $\mathrm{ml}^{-1}$. These rates are far lower than expected rates on the order of $10^{1}$ to $10^{2}$ bacteria flagellate ${ }^{-1} \mathrm{~h}^{-1}$, measured by Fenchel (1982b) and Davis \& Sieburth (1984) over a similar range of bacterial concentrations. The nanoplankton community clearance rates of the microspheres of 1 to $2 \% \mathrm{~d}^{-1}$ were also far lower than expected, particularly given the results of Landry et al. (1984) where daily community clearance rates of bacteria in Kaneohe Bay of 67 and $25 \%$ were measured in 2 dilution experiments. Based on the standing stocks of flagellates, ciliates, and metazoan grazers, Landry et al. (1984) argued that heterotrophic flagellates must account for greater than $90 \%$ of the grazing on bacteria. Studies from other marine sites provide evidence that microflagellates typically ingest substantially more than $1 \%$ of the bacterial standing crop on a daily basis (Kopylov \& Moiseyev 1980, Burney et al. 1982, Fenchel 1982c, Davis \& Sieburth 1984, Sherr \& Sherr 1984).

Sieracki et al. (1987) have recently found that flagellates will release ingested particles from their food vacuoles when killed with typical preservatives, causing an underestimate of actual ingestion rates. Our experiments were subject to this artifact since we used $1 \%$ glutaraldehyde in all but one case to fix flagellates. Sieracki et al. (1987) found that the grazing rates of flagellates were underestimated 48 to $94 \%$ when cells were fixed with glutaraldehyde. Assuming the worst case ( $94 \%$ underestimate) and correcting our field rates, our estimate of the daily clearance rates for the Kaneohe Bay nanoplankton community would range from 20 to $27 \%$ for the 3 experiments. This estimate is clearly more reasonable given the expected impact of flagellate grazing, although grazing by flagellates at this rate would not control bacterial growth (Landry et al. 1984).

Recent studies which employed fluorescent micro- spheres to measure the ingestion rates of planktonic ciliates (Børsheim 1984, Sanders \& Porter 1986, Sherr et al, 1987), the chrysophyte Dinobryon (Bird \& Kalff 1986, 1987, Sieracki et al. 1987), and a variety of nonpigmented flagellates (Cynar \& Sieburth 1986, McManus \& Fuhrman 1986, Sieracki et al. 1987) provide evidence that some protists discriminate against microspheres. Sherr et al. (1987) found that oligotrichous ciliates and mixed populations of estuarine flagellates ingested comparably sized fluorescently labeled bacteria at much higher rates than microspheres (Sherr et al. 1987). This difference cannot be attributed to preservation artifacts since the same preservative (buffered formalin) was used in experiments with the microspheres and labeled bacteria. McManus \& Fuhrman (1986) measured grazing rates of $0.6 \mathrm{mi}$ crospheres flagellate ${ }^{-1} \mathrm{~h}^{-1}$ for a small chrysomonad flagellate in the laboratory and noted that the estimated bacterial clearance rates were considerably lower than those measured by Fenchel (1982b), using other methods. Cynar \& Sieburth (1986) report maximum clearance rates of 0.4 to $1.2 \mathrm{nl} \mathrm{h}^{-1}$ for 4 species of flagellates using fluorescent microspheres. These rates are 1 to 2 orders of magnitude lower than rates previously measured for some of the same isolates in an earlier study in their laboratory (Davis \& Sieburth 1984). Finally, Sieracki et al. (1987), using an appropriate preservation method, report microsphere ingestion rates from 3 experiments for several non-pigmented flagellates of 1 to 4 spheres cell ${ }^{-1} h^{-1}$ at sphere concentrations of 1 to $2 \times 10^{7} \mathrm{ml}^{-1}$. These rates correspond to a clearance rate range of 0.04 to $0.3 \mathrm{nl} \mathrm{cell}{ }^{-1} \mathrm{~h}^{-1}$. Again these rates are lower (by 2 to 3 orders of magnitude) than previously reported laboratory measurements of flagellates feeding on bacteria at similar concentrations (Fenchel 1982b, Davis \& Sieburth 1984). Together, these results and our own studies of flagellates imply that many phagotrophic protists may actively discriminate against inert fluorescent particles.

We conclude that the microsphere method is an accurate and reasonably precise technique for measuring the ingestion rate of particular grazers like Cyclidium sp. The crucial assumption that microspheres are ingested at the same rate as bacteria was upheld for this ciliate. Similarly, Dinobryon ingested microspheres at rates comparable to radiolabeled bacteria (Bird \& Kalff 1986), and several species of scuticociliates and peritrichs ingested microspheres at rates similar to those measured using fluorescently labeled bacteria. (Sherr et al. 1987). Given the problems of preservation (Sieracki et al. 1987) and the evidence of discrimination against microspheres by some ciliates and flagellates, the current method does not appear to be suitable for estimating community rates of grazing on picoplankton by phagotrophic microbes. 
Acknowledgements. This research was supported by grants from the University of Hawaii Research and Training Fund to M.P. M.B. was supported by the Edwin W. Pauley Foundation and the Hawaiian Institute of Marine Biology. We thank D. Bird, K. Y Børsheim, D. Karl, S. Findlay, J. Fuhrman, E. Laws, G. McManus, and G. Taylor for helpful discussions and reviewing the manuscript. K. Y Borsheim kindly shared his technique of amending microspheres with protein to aid dispersion. Contribution to the program of the Institute of Ecosystem Studies, the New York Botanical Garden.

\section{LITERATURE CITED}

Bird, D. F., Kalff, J. (1986). Bacterial grazing by planktonic lake algae. Science 231: 493-495

Bird, D. F., Kalff, J. (1987). Algal phagotrophy: regulating factors and importance relative to photosynthesis in Dinobryon (Chrysophyceae). Limnol. Oceanogr. 32: 277-284

Børsheim, K. Y (1984). Clearance rates of bacteria-sized particles by freshwater ciliates measured with monodisperse fluorescent latex beads. Oecologia (Berl.) 63: 286-288

Burney, C. M., Davis, P. G., Johnson, K. M., Sieburth, J. McN. (1982). Diel relationships of microbial trophic groups and in situ dissolved carbohydrate dynamics in the Caribbean Sea. Mar Biol. 67: 311-322

Cynar, F. J., Sieburth, J. McN. (1986). The unambiguous detection and improved quantification of phagotrophy in apochlorotic nanoflagellates using fluorescent microspheres and concomitant phase contrast and epifluorescence microscopy. Mar. Ecol. Prog. Ser. 32: 61-70

Davis, P. G., Sieburth, J. McN. (1984). Estuarine and oceanic microflagellate predation of actively growing bacteria: estimation by frequency of dividing-divided bacteria. Mar. Ecol. Prog. Ser. 19: 237-246

Estep, K. W., Davis, P. G., Kellar, M. D., Sieburth, J. McN. (1986). How important are oceanic algal nanoflagellates in bacterivory. Limnol. Oceanogr. 31: 646-650

Fenchel, T (1982a). Ecology of heterotrophic microflagellates. I. Some important forms and their functional morphology Mar. Ecol. Prog. Ser. 8: 211-223

Fenchel, T. (1982b). Ecology of heterotrophic microflagellates II. Bioenergetics and growth. Mar. Ecol. Prog. Ser 8 225-231

Fenchel, T. (1982c). Ecology of heterotrophic microflagellates. IV Quantitative occurrence and importance as bacterial consumers. Mar. Ecol. Prog. Ser. 9: 35-42

Ferguson, R. L., Buckley, E. N., Palumbo, A. V (1984). Response of marine bacterioplankton to differential filtration and confinement. Appl. environ. Microbiol. 47: 49-55

Fuhrman, J. A., McManus, G. B. (1984). Do bacteria-sized marine eukaryotes consume significant bacterial production? Science 224: 1257-1260

Guillard, R. R. L., Ryther, J. H. (1962). Studies on marine planktonic diatoms. 1. Cyclotella nana Hustedt and Detonulla confervacea (Cleve) Gran. Can. J. Microbiol. 8: 229-239 Haas, L. W. (1982). Improved epifluorescent microscopic technique for observing planktonic microorganisms. Annls Inst. océanogr., Paris 58 (S): 261-266

IN RUHEobbie, J. E., Daley, R, Jasper, S. (1977). Use of nuclepore filters for counting bacteria by fluorescence microscopy. Appl. environ. Microbiol. 33: 1225-1228

Hollibaugh, J. T., Fuhrman, J. A., Azam, F. (1980). Radioactively labeling of natural assemblages of bacterioplankton for use in trophic studies. Limnol. Oceanogr. 25: 172-181

Kopylov, A. I., Moiseyev, E. S. (1980). Effect of colorless flagellates on the determination of bacterial production in seawater. Dokl. Akad. Nauk SSSR Biol. Sci. 252: 272-274

Landry, M. R., Haas, L. W., Fagerness, V L. (1984). Dynamics of microbial plankton communities: experiments in Kaneohe Bay, Hawaii. Mar Ecol. Prog. Ser 16: 127-133

McManus, G. B., Fuhrman, J. A. (1986). Bacterivory in seawater studied with the use of inert fluorescent particles. Limnol. Oceanogr 31: 420-426

Newell, S. Y., Sherr, B. F., Sherr, E. B., Fallon, R. D. (1983) Bacterial response to presence of eukaryote inhibitors in water from a coastal marine environment. Mar env. Res 10: $147-157$

Pomroy, A. J. (1984). Direct counting of bacteria preserved with Lugol iodine solution. Appl. environ. Microbiol. 47 : 1191-1192

Porter, K. G., Feig, Y. S. (1980). The use of DAPI for identifying and counting aquatic microflora. Limnol. Oceanogr. 25: 943-948

Porter, K. G., Sherr, E. B., Sherr, B. F., Pace, M., Sanders, R. W (1985). Protozoa in planktonic food webs. J. Protozool. 32: $409-415$

Sanders, R. W., Porter, K. G. (1986). Use of metabolic inhibitors to estimate protozooplankton grazing and bacterial production in a monomictic eutrophic lake with an anaerobic hypolimnion. Appl. environ. Microbiol. 52: 101-107

Sherr, B. F., Sherr, E. B. (1984). Role of heterotrophic protozoa in carbon and energy flow in aquatic ecosystems. In: Klug, M. J., Reddy, C. A. (ed.) Current perspectives in microbial ecology. American Society of Microbiology, Washington, D.C., p. $412-423$

Sherr, E. B., Sherr, B. F. (1987). High rates of consumption of bacteria by pelagic ciliates. Nature, Lond 325: 710-711

Sherr, B. F., Sherr, E. B., Andrew, T. L., Fallon, R. D., Newell, S. Y. (1986). Trophic interactions between heterotrophic protozoa and bacterioplankton in estuarine water analyzed with selective metabolic inhibitors. Mar. Ecol. Prog. Ser 32: 169-180

Sherr, B. F., Sherr, E. B., Fallon, R. D. (1987). Use of monodispersed, fluorescently labeled bacteria to estimate in situ bacteriovory. Appl environ. Microbiol. 53: 958-965

Sieracki, M. E., Haas, L. W., Caron, D. A., Lessard, E. J. (1987). Effect of fixation on particle retention by microflagellates: underestimation of grazing rates. Mar. Ecol. Prog. Ser. 38: $251-258$

Smith, S. V., Kimmerer, W. J., Laws, E. A, Brock, R. E., Walsh, T W (1981). Kaneohe Bay sewage diversion experiment: perspectives on ecosystem responses to nutritional perturbation. Pacif. Sci. 35: 279-402

Taylor, G. T., Pace, M. L. (1987). Validity of eucaryote inhibitors for assessing production and grazing mortality of marine bacterioplankton. Appl environ. Microbiol. 53: $119-128$

Taylor, G. T., Sullivan, C. W. (1984). The use of ${ }^{14} \mathrm{C}$-labeled bacteria as a tracer of ingestion and metabolism of bacterial biomass by microbial grazers. J. Microbiol. Meth. 3: 101-124

Wikner, J., Andersson, A., Mormark, S., Hagström, A. (1986). Use of genetically marked minicells as a probe in measurement of predation on bacteria in aquatic environments. Appl. environ. Microbiol. 52: 4-8

Wright, R. T., Coffin, R. B. (1984). Measuring microzooplankton grazing on planktonic marine bacteria by its impact on bacterial production. Microb. Ecol. 10: 137-149 